\title{
Sociology in Eastern Europe: Trends and Prospects
}

The Seventh World Congress of Sociologists in Varna, Bulgaria, held in September 1970, marked a major stage in the development of social science, particularly sociology, in the one-party states of Eastern Europe. Taking place in the most orthodox country of an increasingly diverse bloc, the congress was characterized by the largest and best-organized participation to date of sociologists from Eastern Europe. One country in the area-Albania-did not participate at all; and Yugoslavia, which is probably the country with the most developed social science community and institutions, had a notably small delegation. Yet the fact is that for prestige reasons, if no other, the East European countries and the Soviet Union did their best to show the state of their current development of sociology. This was shown in both quantitative and qualitative terms. Most delegates presented papers.

This paper was presented at the annual meeting of the American Association for the Advancement of Slavic Studies held in Denver, March 25-27, 1971. (It may be identified as publication A-637 of the Bureau of Applied Social Research, Columbia University.) The paper in no way attempts to be a bibliography of the recent developments in sociology and the social sciences in Eastern Europe. However, a few general notes may be helpful to the nonspecialist. The two best overall references are still East Central Europe: $A$ Guide to Basic Publications and Southeastern Europe: A Guide to Basic Publications, both edited by Paul L. Horecky (Chicago, 1969). International Arts and Sciences Press in White Plains, New York, translates a number of works from Eastern Europe and the USSR and has several journals which are essential to anyone trying to follow the field. See particularly Soviet Sociology, Soviet Psychology, and Eastern European Studies in Sociology and Anthropology (discontinued). The Institute on East Central Europe, Columbia University, has a manual in preparation which should be published this year on sources and references to match the excellent Russian and Soviet Studies: A Handbook for Graduate Students, research manual published by the Russian Institute of Columbia University (mimeographed, 106 pp., 1970). The publishing house Anthropos in Paris not only publishes a number of works by East European sociologists and other social scientists, but through its two journals, L'Homme et la Société and Autogestion, is an excellent source for the most recent developments in that field. It has a strong Marxist humanist emphasis. Praxis, the journal of the Zagreb circle of philosophers, issues an international edition annually with articles in French, English, and German. A number of the studies sponsored by the Rumanian Academy of Sciences are published in French. The Polish Sociological Association publishes a semiannual journal in English, Polish Sociological Bulletin. The Yugoslav Research Guide (Belgrade, 1969) is a lengthy description of all institutions conducting research, including social science research, published in English and French.

A good general guide to the current materials is George Fischer and Walter Schenkel, Social Structure and Social Change in Eastern Europe, Occasional Publications no. 15, Foreign Area Materials Center, University of the State of New York, State Education Department, 1970. 
Although I will concentrate on Eastern Europe rather than the USSR, one should note that it was the massive participation of the Russians, with over 300 delegates, that set the pace at Varna. None of the delegations quite matched the Bulgarian one, with 501 mostly newly formed sociologists, but substantial numbers were present from Poland (174), Hungary (74), Czechoslovakia (64), and East Germany (56). The Rumanians and Yugoslavs had roughly the same number of delegates, around 40 each. ${ }^{1}$ Although some of the betterknown Czechoslovakian sociologists were absent because of the anomalous position created by the invasion and subsequent "normalization," the rest of the delegations were fairly representative of the state of social science and sociology in their respective countries.

Not all countries are on the same level of development, and there are diverse definitions of the subject-sociology. The crucial variable is of course not the technological level of modernization and industrialization, but rather a combination of the degree of liberalization and the academic tradition of a given country. Present sociologists range from former economists and social philosophers to demographers and ethnographers, with a small number actually trained in sociology. They are generally products of the faculties of philosophy and law, with some from the higher party schools (institutes or schools of Marxism-Leninism) and the faculty of economics.

Yugoslavia and Poland have established institutional ways of training sociologists, with a fair proportion holding doctorates in sociology obtained through graduate departments of sociology or psychology (social psychology) or the Academy of Sciences, which is a degree-granting institution in Poland. Both countries have a number of sociologists who received some of their training in Western Europe or the United States. Even in Yugoslavia, with the most developed structure of undergraduate and graduate training for sociologists, the professional journals complain that a substantial number of persons doing research or teaching social science and sociology are trained in other disciplines (philosophy and history primarily). This is obviously even more common in the other East European countries.

It was Poland that pioneered in the rebirth of sociology in Eastern Europe, by re-recognizing it as a legitimate academic discipline, and that country still acts as a transmission belt for other East European countries (always excepting Yugoslavia), and even for the Soviet Union. Thus, while

1. Attendance was increased because the congress was held in Bulgaria, if for no other reason than the problem of convertibility of funds which plagues East European social science institutions. Nevertheless, any comparison with attendance figures at the previous world congresses will show that an enormous qualitative leap in attendance is involved (see John Shippee, Empirical Sociology in East European Communist Party States, Research Paper no. 12, Stanford Studies of the Communist System, November 1966 , p. 31A; I cite this work with some hesitation, because it is generally so poor and inaccurate as to verge on the scandalous). This is a reflection of the increasing legitimacy of the discipline. 
Western sociology is often almost inaccessible to the Soviet scholars, Polish sociology in translation acts as the bridge.

Czechoslovakia had witnessed a rapid development of sociology in the period preceding and during the Prague Spring. This development, while not wholly reversed, is currently very slowed down. A good indication is that the Department of Sociology and the Department of Methodology in the Czech Academy of Sciences have been abolished and some of the remaining personnel have been absorbed in the new Department of Philosophy and Sociology. (They thus came back in line with most East European countries in this respect.) A number of chairs of sociology have been abolished, as has the Institute of Political Science (formerly the Institute for Marxism-Leninism). Nevertheless, it was after these events that a major study on the Czechoslovak social structure was published-Ceskoslovenská společnost by Pavel Machonin and team. ${ }^{2}$ It should also be noted that Dr. Miloš Kalab, former director of the Department of Sociology of the Academy of Sciences, was present at Varna and presented a major paper. ${ }^{3}$ This is the more remarkable since sociologists in general, and Kalab and Machonin in particular, were associated with the Prague Spring and the general opening up and humanization of Marxism and sociology in Czechoslovakia.

Some of the work of Czechoslovak sociologists will be discussed later on, but the situation of sociology in that country can be taken as a touchstone for its prospects in Eastern Europe. Sociology has become a legitimate academic discipline, within limits which vary from country to country. For the time being this condition appears to be irreversible, always excepting a major change in the Soviet Union which would wipe out Soviet sociology. These limits are related both to the use of sociology by the authorities and to the scope of the problems with which sociologists can occupy themselves. One general rule can be applied: sociology in each East European country has to pass through the stage of being primarily a polemic against bourgeois sociology. It begins to free itself from orthodoxy through micro-studies of a relatively technical type dealing with nonissues.

A second general stage is represented by the kind of research that deals with social problems of a general, "nonpolitical" type, oriented toward making minor and fairly narrow policy-implementing recommendations. At this stage there are a number of descriptive studies (a form of social statistics) which supplement the census and other such data. The descriptive studies tend to

2. Pavel Machonin et al., Ceskoslovenská společnost: Sociologická analyza sociální stratifikace (Bratislava, 1970). The study was carried out in 1967 and is both thorough and sophisticated. A manuscript of a translation was prepared in London in 1969, the fate of which I do not know.

3. Miloš Kalab, Le Matérialisme historique et la conception marxiste de la sociologie, Proceedings, VII World Congress of the ISA (Varna, 1970). See also "A propos de la problématique des élites et de la formation de l'opinion publique dans la république socialiste de Tchécoslovaquie," L'Homme et la Société, no. 14, October-December 1969. 
be sharply circumscribed in that the categories used are politically defined (e.g., "strata" in stratification studies).

The third stage is characterized by an expansion of research, including some of the general social problems of the society. Sociologists begin to act as an important feedback mechanism for the system. In effect they attempt to provide for the leadership a substitute for a critical press. The range of problems is expanded; public opinion surveys are used, although the findings are often restricted. At this point the problems of technique and methodology assume considerable importance, as does the education of new technically trained cadres. This is also the stage at which contact with the wider social science community is felt to be necessary.

After the three formative stages of development of sociology in Eastern Europe, one usually finds an advanced group of professionals working in the field. They have, by this time, freed the discipline from the tutelage of direct ideological control and from the traditional disciplines within which it developed as a subbranch. The next two stages are more difficult. In the first, sociology begins to deal with some of the central problems of the given society -social mobility, stratification, participation, and political socialization. The research is now generally published and it is less directly policy-oriented. Contact with colleagues from other countries becomes relatively normalized, as is access to publications in the field. An interest begins to develop in comparative studies.

The last or fifth stage is a level at which one can hardly speak of the "sociology" of a given country, for the discipline begins to show a diversity among a number of sometimes contending parties. Different models of the society are presented; scholarly polemic becomes the norm in the profession. Comparative research is accepted as normal and desirable. Some sociologists, to be sure, are "constructive," but others are critics of the society. In short, this stage represents the move from a consensus mode to a conflict one, not only in the profession but also in how the society itself is perceived.

This developmental typology is of course schematic, as all typologies are. It is also true that at each successive stage there are some who continue to work at the preceding one; for example, Yugoslavia is now in the last stage of development, but one can find work there that is typical of all the preceding stages. What these stages represent, therefore, are the limits of the possibilities for work at a given time in a given country for sociologists.

My impression from the papers presented at Varna is that in terms of the typology used the countries could be distributed roughly as follows:

1st stage: all have gone past this primary stage

2nd stage: Bulgaria, Rumania

3rd stage: East Germany, Hungary, Czechoslovakia (post-"normalization") 4

4. While I think that the situation of sociology has retrogressed in Czechoslovakia, sociologists there are still in a good position to resume their advance. During the pre- 
4th stage: Poland and Czechoslovakia (pre-"normalization")

5th stage: Yugoslavia

I am not discussing the quality of work of the sociologists in these countries, but only the limits within which they generally can and do work. Thus, for example, some excellent work has been done in Hungary which is in no sense less competent than the work done by the Poles or Yugoslavs in the same field (e.g., rural sociology or sociology of education). It is merely that the range of problems with which they deal is still far more limited.

The discussion above was directed to the problem of research, and I have used the more general term "social science" almost interchangeably with sociology. This is in part because the training of many of the practitioners of "sociology" blurs the distinctions between the various branches of social science, and for that matter between social science and political dogma, particularly in the first three stages of development. When one examines the work in these early stages, it becomes clear that much of it is, when empirical, more related to social psychology, demography, traditional ethnography, and ethnology, with doses of fairly primitive industrial psychology and some cautious public opinion research.

A recent reference to the work of East European and Soviet sociologists by Paul Lazarsfeld illustrates some of the problems of Western social scientists when attempting to describe the work of their colleagues. ${ }^{5}$ Lazarsfeld uses the term "Marxist sociology" interchangeably with "sociology in the Communist countries" and "concrete sociology." These are in my view three distinct concepts. (One could even argue that the most fruitful development of Marxist sociology in recent years has taken place in the West.) "Concrete sociology" is certainly not the term the Yugoslavs, Poles, or Czechoslovaks (in the prenormalization period) would use to describe their schools of sociology. This tends to lump together the East European countries and to stress their similarities rather than their far more interesting diversities. I suspect this is a common mistake, based on placing too much emphasis on the normative statements about what sociology should be rather than on the work being done. ${ }^{b}$

There is a generational cleavage among East European sociologists and those in the USSR which can be seen in the emphasis placed on the normative descriptions of the discipline. Some of the older sociologists continue to write

ceding period a number of competent sociologists were trained who can, given a change in the political climate, advance the discipline relatively rapidly.

5. Paul Lazarsfeld, "Sociology," in Main Trends of Research in Social and Human Sciences (Paris and The Hague: Mouton and UNESCO, 1970), pp. 94-103.

6: An even more serious difficulty with the Lazarsfeld piece is to be found in the lengthy footnote (n. 29a) which cites "works of Marxist inspiration dealing with general sociological problems," citing uncritically in turn an article by Professor Fedoseev of the USSR. The only works referred to, of course, are by Soviet sociologists. It would cause considerable surprise among the far more prolific and significant Polish and Yugoslav sociologists to be informed that Marxist sociology is Russian sociology. 
papers and books that attempt to relate sociology to orthodox (official) Marxism-Leninism, thus defining the discipline as legitimate. This is partly because a number of them are not sociologists at all but rather party ideologues or social philosophers. The younger generation, although it has its share of ideologues, is far more interested in empirical research, and pays little attention to theory except for an occasional perfunctory genuflection, often out of context, to formal ideology.

Political sociology, dealing with the social rather than the normative bases of power in the existing socialist societies, is one of the last branches of sociology to emancipate itself from the ideological strait jacket and from official publicists of the regimes. It is probably the least-developed branch of sociology in Eastern Europe. This can be seen in the excellent discussion and bibliography on political sociology in Eastern Europe that Jerzy Wiatr published in $1964 .^{7} \mathrm{~A}$ large proportion of the entries refer to descriptive works by classical political sociologists, polemics against functionalism, or assertive statements defending the given political system. Those works that would be recognized by Western sociologists (even Marxist Western sociologists) as dealing with the subject of political sociology are almost without exception from Poland or Yugoslavia.

\section{East Germany}

The place of sociology in various East European countries is closely related to the stage of development of the discipline, except that the formal statements about the role of sociology are often far more rigid and retrograde than the actual practice. One of the more rigid statements is by the East German sociologists: "The development and function of sociological research in the German Democratic Republic is determined by the function and the development of the Marxist-Leninist social science in socialist society. . . . Together with all other social sciences of Marxist-Leninism, Marxist-Leninist sociology forms a theoretical basis for the scientific policy of the revolutionary party of the working class in constructing the new social order" (my emphasis). ${ }^{8}$ In short, sociology is an integral part of the "other social sciences of Marxist-Leninism" with a direct policy function of informing (theoretically, and one would hope empirically) the scientific policy of the party. The function and the client are both clearly defined. This is, however, only a normative statement. When one examines the work in progress, after noting that East

7. Jerzy Wiatr, Political Sociology in Eastern Europe (Oxford: Basil Blackwell, 1965) (Current Sociology, vol. 13, no. 2). This book is a discussion of the trends and a bibliography.

8. Erich Hahn and Horst Taubert, "Marxist Leninist Sociology in the GDR," in Sociological Research in the German Democratic Republic (Berlin, 1970), p. 9. 
Germany was one of the late starters in this field-although preceding the Soviet Union in informal research-it becomes evident that the range is wider and more mundane. Much of the work is on such a micro-level that its applicability to the policy of the party in constructing the new social order is many levels removed. A considerable proportion of the studies-rather than papers -are unsurprisingly in the field of industrial sociology, mainly factory studies. These are generally descriptive, although some do seem addressed to policy problems (absenteeism, desire for promotion, general work motivation, etc.).

The more practical definition of sociological research given by the East Germans, and the one guiding the current empirical work, is as follows: "Generally, sociological investigations are carried out in an empirically given area which is limited by time and space. The researcher or the person conferring the commission is interested in the concrete state of development, the specific nature of a certain phenomenon or social process in a certain plant or industrial branch at a given time. From this marked area, the results should be representative and furnish a clear statement. . . . Statistical material and concrete descriptions are generally included in reports about sociological investigations. And they are of such a nature that they permit the leaders of the area of investigation to derive conclusions in order to evaluate and influence the individual process concerned." In distinction from the first quotation, which incidentally is from the same article, this represents a perhaps somewhat narrow and crassly empiricist description of the discipline, and would be recognized as such by most Western sociologists.

From the materials submitted at Varna it is evident that the East German sociologists are at the beginning of a rising curve of development of empirical sociology, which is increasingly brought to bear on nonsystemic social problems of that society. At least three universities (Berlin, Leipzig, and Halle) have sociological commissions. In the fall of 1969 the first Congress of MarxistLeninist Sociology in the GDR was attended by over five hundred participants. The themes of the sessions, other than the attacks on bourgeois sociology, were industrial sociology, rural sociology, youth, and culture. During 1970 a major one-volume encyclopedia of sociology was issued which is, according to my Polish sociologist colleagues, a very creditable work and marks a further step in the legitimation of sociology as a discipline in East Germany.

I was personally impressed by at least one paper, "Problems Concerning the Sociological Analysis of the Social Structure of Socialist Society,"10 which stays within the bounds of orthodoxy yet cites Dahrendorf, Mills, Lenski, Kingsley Davis, and even Eisenstadt in a reasonably scholarly manner, and at least begins to deal with some of the questions in political sociology.

9. Ibid., p. 10 .

10. Manfred Lotsch, Hansgunter Meyer, and Horst Taubert, in Sociological Rescarch, pp. 61-72. 


\section{Czechoslovakia}

What happens when sociology in an East European country moves past the formative three phases can be best illustrated by Czechoslovakia in the period 1968-69. It represents an almost ideal type of my fourth stage, and is convenient to examine because the development was compressed in a relatively short period. Our examination is made easier by a study published in 1970 by Michal Ilner and Helena Steinova on research in Czechoslovakia during that period. Their data are based on a questionnaire sent out by the Archive of Sociological Research of the Czech Academy of Sciences in the spring of 1969 to project directors of the 107 existing larger research projects. Not examined were a number of smaller projects, mostly sponsored by individual enterprises and local governments. The first table shows the sponsoring organizations. ${ }^{11}$ In table 2 we see a rough distribution of the topics of the

Table 1. Sponsoring Organizations

\begin{tabular}{lc}
\hline Institutions & Percent \\
\hline Universities & 35 \\
Academy of Sciences & 27 \\
Research institutes & 21 \\
Mass organizations & 8 \\
State organizations & 7 \\
Industry & 2
\end{tabular}

a This category covers professional research in. stitutes associated with specific ministries, such as commerce, construction, and so forth.

\section{Table 2. Topics of the Studies}

\begin{tabular}{lc}
\hline Subject Matter & Percent \\
\hline Society and its structure & 48 \\
Economic problems & 44 \\
$\begin{array}{l}\text { Problems of culture and } \\
\text { civilization }\end{array}$ & 40 \\
$\begin{array}{l}\text { Demographic and ecological } \\
\text { problems }\end{array}$ & 33 \\
Political and legal problems & 31 \\
Social problems \\
$\quad$ (narrowly defined)
\end{tabular}

studies. There is considerable overlap here, since a number of the studies deal with more than one topic. The observation of the authors seems appropriate: "The distribution of the subject matter seems to reflect the developmental trend in Czechoslovak society; the initial wave of studies related mainly to the economic system. This is gradually being balanced by an increasing interest in more typical sociological problems, such as studies of social structure and stratification. Attention is beginning to be paid to the problem of the political system." However, a more significant breakdown is shown in table 3, which shows which other disciplines were involved in the research. Again we have an overlap.

Table 3 illustrates the pre-eminent role of psychology and social psychology in the early development of real sociology in Czechoslovakia. To the 43 percent for those subjects, I would add pedagogy (19 percent), since most of

11. Michal Ilner and Helena Steinova, Materials in the Sociological Archives of the Caechoslovak Academy of Science (mimeographed, 1970), a translation of an article that appeared in the Czech Sociological Journal in the fall of 1969. 
Table 3. Other Disciplines Involved in the Research

\begin{tabular}{lcllc}
\hline Discipline & Percent & & Discipline & Percent \\
\cline { 1 - 1 } Psychology and & & & Legal sciences & $\mathbf{8}$ \\
social psychology & 43 & & Aesthetics & 6 \\
Economics & 28 & & Urban studies & 4 \\
Pedagogy & 19 & & Organization and management & 3 \\
Political science & 15 & Geography (ethrography) & $\mathbf{3}$ \\
Demography & 14 & History & 2 \\
Medical sciences & 11 & Other & $\mathbf{5}$ \\
\hline
\end{tabular}

the researchers in this field in East European countries are trained in either social psychology or child or educational psychology. The overwhelming majority of the projects used the survey method and questionnaire as the major instrument, and characteristically little or no use was made of secondary data. The range of techniques varied somewhat, as did the methods of sampling. One-stage random sampling and quota sampling were most often used (27 percent and 21 percent, respectively) but more sophisticated techniques, including multistage random sampling, exhaustive sampling, and cluster sampling, were also used. My personal observation of the work of Czechoslovak sociologists at this stage indicated that they were advanced in the use of statistics and methodology, and had begun to use computers fairly extensively. As yet, however, they had little experience in the practical problems of conducting survey research, particularly of special and elite populations.

The theoretical level of Czechoslovak sociology can be gauged by some of the work available in English and French. ${ }^{12}$ It appears to have been affected by two trends which are not necessarily contradictory: sophisticated humanist Marxist synthesis, and almost completely depoliticized methodology and general sociology resembling the functionalist Western models. It is a curious fact that although one can trace a running polemic with a sometimes caricatured functionalism throughout the early development of East European and Soviet sociology, it is functionalism that is found most attractive and "interesting" at the third stage. This is probably because functionalism appears to fit the needs of the system as perceived by its leaders and ideologists at that stage:

12. Among others see Radovan Richta, La Civilisation an carrefour (Paris: Anthropos, 1969; an English version, Civilization at the Crossroads, appeared in 1969, International Arts and Sciences Press, White Plains); Robert Kalivoda, Marx et Freud (Paris: Anthropos, 1968). See especially the edition of L'Homme et la Société, no. 9, July-September 1968, "Sociologie tchécoslovaque et renouveau de la pensée marxiste," as well as the other issues of this journal, and the special edition of Autogestion, no. 1112, 1969, "Conseils ouvriers en Tchécoslovaquie." Working Papers of the International Study of Opinion-Makers, vol. 2 (Bureau of Applied Social Research, Columbia University, B. Denitch, etc.), has two papers on a Czechoslovak study of elites by V. Lamser and M. Kalab. See also issues of the East European Series of the IASP, White Plains, particularly Czech Economic Papers and East European Studies in Sociology and Anthropology. 
conflict is regarded as dysfunctional and an aberration; system maintenance is accepted as a goal; and the function of sociology is thought to be to provide a scientific basis for dealing with conflicts and achieving an equilibrium. In short, sociology joins official ideology in becoming an independent legitimizer of the existing social order. (Thus Parsons is probably the best-known and most highly regarded Western sociologist in the USSR, while C. W. Mills, Gouldner, and Coser are most popular in Yugoslavia and, to a lesser extent, in Poland. A schema could be developed: during the polemic stage and the next two stages of development, statisticians and "strict" methodologists from the West are acceptable; by stage 3 , sociology of stability and system maintenance; by stage four, relatively neutral academic figures; and at the last stage, the sociologists of conflict who are critics of the established social order.)

Before leaving Czechoslovak sociology in the prenormalization period, it is relevant to add that at that time 82 percent of the research projects reported that their findings would be published and accessible without restriction. The major changes which have occurred are in this respect. The results of the public opinion surveys (which were public) and most other studies are generally no longer available. Major studies, if undertaken, will be more directly controlled, and the number of empirical researchers in the prestigious academy and in the universities has been sharply cut back. It should be stated, however, that the institutional bases of the development of Czechoslovak sociology still exist, although they are sometimes merged with other institutions or drastically pruned.

\section{Academies of Science and Universities}

The reason for a fairly detailed discussion of Czechoslovakia is that it can be seen as an example of where the development of social science in Eastern Europe could lead. Today, however, the more typical development is that of the countries in the middle range-Hungary and East Germany. Another aspect that is typical of Eastern Europe-again excepting Yugoslavia-is the dominant position of the academy of sciences in relation to the universities in the discipline. ${ }^{13}$ In these countries it is the academy that has the greater prestige, the better-developed cadres, and more research funds. It also grants the more prestigious doctorates. Therefore the academy generally conducts the most interesting research and pioneers in the development of sociology. When the universities are involved in a newfangled discipline, it is usually through those professors who also hold an appointment in the academy. There are a

13. In East Germany, however, sociological research goes through the Scientific Council for Sociological Research in the GDR, established at the end of 1964. 
number of reasons for this. The main one is that in the system-building stages in Eastern Europe the academies were developed as a Marxist counterweight to the universities. In addition, the universities have tended to stress academic formalism, slow change, and tradition as a defense against the intrusions of the political society. One result is that although persons in traditional disciplines such as philosophy can sometimes use the university as a shelter, there is a resistance toward accepting new disciplines (and therefore departments) into the faculties. This factor is somewhat modified in the case of Poland, which had before the Second World War a strong and well-developed sociological tradition based on the universities.

The framework of the academies permits a forced march in developing a discipline. It is far more difficult organizationally to expand the university staffs for a new field, and considerable development is necessary before it is possible to generate teachers of sociology. When the academy or research institute expands its staff, the new members begin learning about sociology by doing research; thus their rawness presents little problem. The research staff is usually younger, more flexible, and easier to send abroad for training. It is also bound to be more loyal. When the universities begin to move into this field, however, they face a different problem, at least with the first generation of teachers. They cannot be younger scholars who are learning by a process of trial and error (in any case, East European universities do not have a tradition of doing empirical research). They have to systematize, legitimize, and teach a discipline in which they have not been trained and for which the official guidelines of what is permissible are continually changing. The latter generates a particular strain, since a delicate balancing act is required to avoid being labeled an old-fashioned hack, on the one hand, or a non- or anti-Marxist disseminator of bourgeois social science on the other. Neither one is conducive to a successful academic career. The first chairs of sociology are generally filled from two sources: professors of philosophy or logic and professors of psychology. This selection, particularly since a number of the philosophers are either current or former official ideologues, builds in a sharp cleavage between theorists and empiricists-with neither informing the other. The theorists are more abstract and the empiricists more narrowly empirical than is true of their Western colleagues. Because this sharp differentiation is found to a lesser extent in the academies, their products after a formative stage are more likely to be recognized as sociologists by Western standards.

Presumably the solution to this problem can take several forms. In Yugoslavia the academies never played the role assigned to their counterparts in the rest of Eastern Europe. The closest they came was the Institute of Social Sciences in Belgrade (founded in 1956), which was intended to be a Marxist academy. The growing decentralization and pluralism of institutions, however, never permitted the institute to consolidate its position, and the universities 
have vigorously insisted on the need to join research with teaching of sociology. Today it is the university appointment which carries the greater prestige, security, and rewards, and research is increasingly directed by the professors. An alternate solution is for the training of sociologists, including formal teaching, to be turned over to the academies-a solution adopted to a certain extent by Poland and Czechoslovakia.

\section{Hungary, Rumania, and Bulgaria}

Although this paper does not pretend to be an overall survey of sociology in Eastern Europe, concentrating as it does on some general trends in sociological research and the prospects of the discipline, a few words should be said about the situation in Hungary, Rumania, and Bulgaria.

Works by Hungarian sociologists are reasonably accessible to Western scholars, particularly in French. ${ }^{14} \mathrm{~A}$ good deal of research has been carried out in the fields of rural, family, and educational sociology, culture and leisure time, social stratification, social mobility, and attitude research. There are two centers for public opinion research, one with the Academy of Sciences, the other with Radio-TV Budapest. The academy is the center of research in general. Several Hungarian sociologists, particularly András Hegedủs, have published abroad. ${ }^{15}$ There is a cautious development of political sociology-as distinct from legal studies. Sociological research and writing have been fairly well popularized in outlets such as the New Hungarian Quarterly. My impression is that in several fields sociologists have begun to act as social critics, within bounds acceptable to the system. This is the case with some recent studies of youth (in which a distinction between hippies and hooligans is emphasized, with an implied critique of the treatment of the former), rural conditions, and housing. Much of the material is generally available, as are statistical yearbooks and census data.

In Hungary two persons have made a remarkable impact on the development of social science and sociology. György Lukács, who is probably the most prestigious Marxist social philosopher living, has played a major role

14. For the French translations, the best publisher is Anthropos in Paris. See especially András Hegedüs, Etudes sociologiques (Paris, 1969), which includes works by Hegedüs, Lukács, György and Maria Markus, Erdei, Heller, Ferge, Konrad, and others. See also the contributions by Hegedüs, Markus, and Szesztay in Lauwe, ed., Aspirations et transformations sociales (Paris, 1970). Besides the articles in the Nere Hungarian Quarterly, there is of course in English the excellent, if somewhat old-fashioned rural study, Proper Peasants. Also, Egon Szabady has published extensively abroad, including Hungarian Fertility and Family Planning Study of 1965-66, IPPF Conference (Copenhagen, 1966), Preventive Medicine and Family Planning (Hertford, 1967), "La Population des pays socialistes européens," Population (1966), and so forth.

15. See his Etudes sociologiques, cited in note 14, and La Structure de la société socialiste (Paris: Anthropos, and Hungarian Academy of Sciences, 1967). 
in this development. His protection of the discipline, although giving it a strong philosophical and cultural emphasis, was crucial in freeing it fairly early from direct party tutelage, and winning it at least an academic freedom. The second figure is András Hegedüs, who had been premier in the Nagy government. Hegedüs trained a generation of younger sociologists, including Zsuzsa Ferge, György Markus, Maria Markus, and András Szesztay. This circle, with fairly limited resources, has produced increasingly important research. The relationship between sociologists and the authorities seems to be one of cautious neutrality-the independence of the profession was purchased in the early stages by consistently maintaining a "low profile." Hungary, therefore, differs in one other respect from its neighbors: there has been no forced march of the development of sociology. A far more natural organic growth has taken place which will probably have an increasing impact on the development of sociology in the area. I believe that in terms of my typology Hungary is moving from stage 3 to stage 4 .

The case of Rumania is more complicated. A well-developed prewar tradition of rural sociology of the French school (around Professor Dimitrie Gusti) existed in Rumania. Sociology as a subject, however, was revived relatively late (1965), ${ }^{16}$ first as "concrete social research," then as "concrete sociology." A reasonable picture of the ongoing research and the state of current sociology is given in the recent edition of the Romanian Scientific Abstracts, ${ }^{17}$ the Selected Bibliography, and Sociological Abstracts, prepared for the Varna Congress (all available in English). Up to the founding of the Center of Sociological Researches (1965) in the Academy of Sciences, social science research went on through the Center of Ethnography and Folklore, the Center of Anthropological (mostly physical) Researches, and the Central Statistical Board. The first courses in sociology were organized in 1966 (concrete sociology rooted in Marxism-Leninism) in the sociological laboratory of the University of Bucharest. The first empirical projects were begun the same year, mostly consisting of rural studies, some studies of time-budgets and absenteeism, and studies of the "development of socialist culture."18

The Rumanian sociologists are organized along six lines of activity: (1) sociological theory, mostly "concrete sociology" and science of society (i.e., Marxism-Leninism) ; (2) history of sociological doctrines in Rumania; (3) historical sociology, basically social history-orthodox Marxist historiography; (4) direct investigation of social facts in today's Rumania (this area

16. For the Varna Congress, the Academy of Social and Political Sciences in Bucharest issued in 1970 The Romanian Sociological Abstracts (125 pp.), which includes a short review of the development of Rumanian sociology.

17. Published by the Academy of Social and Political Sciences, December 1970, as part of a series, this is issue no. 12 .

18. Romanian Sociological Abstracts: see the article by Miron Constantinescu (pp. 1-9). 
carries out most of the empirical research in industrial sociology, public opinion, social stratification, education, urbanization, youth and rural problems); (5) health and demography, mostly for various ministries and state agencies; and (6) sociological methods, where the technical adaptability of research methods for policy research is developed.

A major impetus for the organizational development of sociology in Rumania will probably come from the newly organized Academy of Social and Political Sciences (1970). This marks the growing acceptançe of sociology as a policy science, increasingly used to help solve practical problems of administration and modernization of Rumanian society. This has been succinctly stated by the present director of the academy: "All these lines of sociological activity favor the carrying out of investigations of an increased practical value, the results of which can be taken into consideration for practical ends and immediately applied by the decisional bodies in the current activity of building the many-sidedly developed socialist society" (my emphasis) ${ }^{19}$

Rumanian sociology is well organized and enjoys considerable support from the government. It gets much better publicity and resources than the more autonomous and better-developed sociology in Hungary. When one examines the work described in the attractively printed abstracts, however, the limitations become all too clear. Very little of the work described is based on empirical research; much of it cannot by any effort be called sociology. It represents a rehash of simplified Marxist "science of society" themes, social history, normative descriptions, and so forth. There are some modest village studies and studies of urban and industrial problems (absenteeism and productivity). This can be contrasted with the work of psychologists who do considerable empirical research in social psychology on attitudes, youth, education, and socialization.

My personal impression is that in the near future sociology will replace the courses on the science of society (Marxism-Leninism) in the universities in Rumania. ${ }^{20}$ In that case a sharp distinction will continue to exist between those sociologists who act as academic legitimizers of the social system and regime and those who do increasingly "practical" policy research for the decision-makers. The solid institutional place of sociology, combined with the increasing contacts abroad that Rumanian sociologists are developing, will soon, in my opinion, create pressures to broaden, diversify, and advance the

19. Ibid.

20. In addition to a number of meetings with Rumanian sociologists at Varna, I visited the new Academy of Social and Political Sciences in the late fall of 1970. A remark by one of my Rumanian colleagues sums up the present situation, I believe: "Our leaders need a great deal of information about what is happening; the trouble is that many of them do not want to know." 
type of work they can do. It is reasonable, therefore, to expect continued development of sociology in Rumania.

The situation of sociology in Bulgaria is in many ways similar to that of Rumania. We have a relatively late formation of institutional bases, beginning with the establishment of the Institute of Sociology at the Bulgarian Academy of Sciences in Sofia in 1968. To be sure, the publication prepared by the academy for the Varna Congress states that "sociological knowledge in Bulgaria may be said to have originated soon after its establishment as a state in 681,"21 but that claim (that Bulgaria preceded the world in this development) can be taken somewhat whimsically. The Bulgarians, unlike the Poles, Yugoslavs, Hungarians, and Rumanians, do not claim that there is a continuity between sociology in Bulgaria today and any prewar academic tradition. The only tradition granted legitimacy is that of some national revolutionary figures in the War of Liberation against the Turks in 1878, as well as that of the prewar Marxist leaders. However, this is more than made up for by the transmutation of most ideological and political works and speeches into sociology since the establishment of the Communist Party in power. Thus "Georgi Dimitrov's report to the Fifth Congress of the BCP (1948) . . . contains a profound sociological analysis [my emphasis] of the preparation and victory of the socialist revolution in Bulgaria and a forecast of its development along the road to socialism and communism.",22

The road to institutional legitinacy for sociology began in 1955 at the Institute of Philosophy of the academy with an organized discussion of a draft monograph by Oshavkov, "Historical Materialism and Sociology." In the years that followed, it was primarily philosophers around the academy who began moving into what was to become sociology. This is still the case; a number of the major leaders of sociology are former (Marxist-Leninist) philosophers. Bulgaria is one country in which social psychologists did not play a major role in starting empirical social science research.

It is only since the first years of the sixties that sociology has become recognized as a nonphilosophical general social science, and "concrete" sociological research has been undertaken. The first large-scale survey, in 1962, was on religion and is described in a collective work edited by Oshavkov, "The Process of Eliminating Religion in Bulgaria." Al Although the study was politically oriented, a relatively high statistical sophistication is shown in the analysis and sampling procedures. Other large-scale surveys followed, especially after the establishment of the Sociological Institute. These include a study of town and village populations ( $\mathrm{N}: 18,996)$, also directed by Oshav-

21. Vassilev, Draganov, and Mikhailov, Sociology in Bulgaria, Bulgarian Academy of Sciences (Sofia, 1970; in English, 111 pp.). The citation is from page 7.

22. Ibid., p. 21.

23. Ibid., pp. 35-53. 
kov; a survey of rural youth and migration by the Center of Sociological Research of the Central Committee of the Young Communist League (N: $11,250)$; and a number of smaller industrial studies on work fatigue, absenteeism, motivation, and so forth. The very large samples show that considerable resources were made available and invested in research.

Today a large number of institutions exist which are called sociological. Most of them are attached to policy-making bodies or mass organizations. ${ }^{24}$ There are also a number of regional centers in larger cities, an expanding interest in problems of "scientific management," manpower training, and so forth-all of which are in the newly enlarged domain of sociology. This is clearly a major directed expansion of institutionalized sociology to serve the system-managers. Sociology is a catchall for "science of society," social sciences, social work, policy research for organizations, and industrial sociologyin short, the nightmare of the younger radical sociologists in the West and Yugoslavia: a social science wholly and explicitly at the service of the existing system. Nevertheless, there are two other aspects which should be noted. The development of sociology as a system-legitimizer and conflict-avoider in this context represents a move from the far more direct and crude methods of political intervention. It is a bureaucratization and routinization of the system, and is perceived by the leadership not only as useful but as more useful than the older methods. Therefore, one can expect that in Bulgaria, too, sociology will continue to expand. In my view, it is better developed today than in Rumania, despite the greater publicity and contacts of the sociologists from that country. One can also hope that as sociology develops in Bulgaria, it will begin to move out of its present strait jacket.

\section{Poland and Yugoslavia}

In the case of Poland and Yugoslavia, we suffer from an embarrassment of riches for any short overview paper. This is not too serious, since much of the work of the leading Polish and Yugoslav sociologists is available in translation. In both countries sociologists are accustomed to contact with colleagues the world over; they engage in extensive exchange of graduate students and

24. These include: (1) Sociological Information Center of the Central Committee of the Bulgarian Communist Party; (2) Sociological Survey Center of the Central Trade Unions; (3) Sociological Youth Survey Center of the Central Committee of the Youth Organization; (4) Research Center of Radio and TV (which does whatever opinion research is done); (5) Department of Sociology of Labor in the Ministry of Labor; (6) Military and Sociological Research Center in the Ministry of Defense; (7) Consumers Demands Research Center; (8) Sociological Research Center at the Bulgarian Book State Trust; (9) Sociology of Sports Research Center (at the Ministry of Sports); (10) Crime Research Council at the Chief Prosecutor's Office; (11) Central Committee for Combating Juvenile Delinquency; and so forth. 
faculty, and have been a general part of the larger academic sociological community for well over a decade. I would therefore like to stress only a few more relevant aspects of the situation in these two countries.

Polish sociologists are the first to have become known to the West. A reflection of this can be seen in one of the best-known readers on social stratification in the United States, which includes the work of several Polish sociologists. ${ }^{25}$ A special edition of the International Social Science Journal (no. 2, 1957) was devoted to Polish sociology. The Polish Sociological Association has been publishing a semiannual bulletin in English and French since 1960, and the Academy of Sciences has a regular exchange program with French sociological and historical centers. A number of better-known Polish sociologists have taught in universities in the United States and Europe, and it is my personal impression that most of the younger scholars have spent some time abroad. The hardening of policy in the late sixties, which resulted in the emigration of several of the best-known Polish sociologists, has not materially affected the range of work being carried out. On the other hand, the fact that Baumann and Kolakowski, to mention two of the better-known figures, had no difficulty in receiving appointments in major universities abroad is testimony to the level of Polish social science.

As far as I know, there is no major branch of sociology or sociological research that is not represented in Poland (the possible exception being ethnomethodology). In stratification, political sociology, and rural sociology Poland is probably ahead of a number of West European countries. To be sure, a major academic tradition existed before the war, and Poland was the first East European country to resume the development of sociology as a social science. This means that there is a large network of institutions employing sociologists, and that their association has sufficient internal resources to continue this development.

25. Compare the latest edition of the reader on stratification by S. M. Lipset and Reinhard Bendix with the original edition.(Social Mobility in Industrial Society). Other accessible works by Polish sociologists, in addition to Wiatr, Political Sociology in Eastern Europe, include Jan Szczepánski, Polish Society (New York, 1970) ; Adam Schaff, Langage et connaissance (Paris: Anthropos, 1969); Jan Szczepánski, Problèmes sociologiques de l'enseignement supérieur en Pologne (Paris: Anthropos, 1969); and Janina Markiewicz-Lagneau, Education, égalité et socialisme (Paris: Anthropos, 1968). A number of important articles appeared in L'Homme et la Société, particularly Jan Szczepánski, "La Sociologie marxiste empirique," no. 1, 1966. An excellent analytical article, although somewhat dated, is Leopold Labedz, "Sociology and Social Change," Survey, no. 60, July 1966, which discussed East European sociology with special attention to Poland. See also Zygmunt Baumann, "Economic Growth, Social Structure, Elite Formation: The Case of Poland," International Social Science Journal, 16, no. 2 (1964): 203-16; Krzysztof Ostrowski and Adam Przeworski, "A Preliminary Inquiry into the Nature of Social Change: The Case of the Polish Countryside," International Journal of Comparative. Sociology, 8 (1967): 25-43; and Jerzy Wiatr, "Politics and Social Change: Poland," International Journal of Comparative Sociology, 7 (1966) : 237-46. 
The most prestigious institution is the Academy of Sciences, which has a large Institute for Philosophy and Sociology, with a number of specialized departments. The student demonstrations in 1968 resulted in a purge of some of the faculty and a reduced influence of sociology in the university. However, sociology remains a subject taught there. The graduate training is in the academy in most cases. There are also a number of smaller institutes, research centers, and study teams attached to a wide variety of bodies. Centers exist in major towns besides Warsaw, and instruction of sociology is carried on in the provincial universities.

The purge in 1968 was directed at those who were beginning to develop a critical sociology-particularly in the realm of theory, stressing Marxist humanism. I believe that it is possible in Poland to be a non-Marxist sociologist, provided one does not take a critical stance toward Polish society and its institutions. What is not possible is to develop and apply a conflictual model to contemporary Poland. Thus one finds either those sociologists accepting the official party ideology and program, with minor criticisms, or empiricists and positivists who tend to deal with the less "political" topics and research. That is, it is possible in Poland to have a degree of academic detachment and political neutrality, in contrast with Rumania, Bulgaria, East Germany, and, recently, Czechoslovakia. There is very little jargon in most of the articles published, except of course sociological jargon. The critiques of Western sociologists which appear are, by and large, competent, academically serious, and well informed. In Poland, I would say, one can begin to speak of a "Marxist sociology."

Although Polish sociology got off to an early start, it was affected by the stagnation and immobility of the later days of the Gomulka regime. The fact that several of the major figures of Polish sociology became politically persona non grata did have an effect in limiting funds and the scope of the discipline. Above all, it cut down on foreign contacts and set back comparative research. My feeling is that for the past four or five years there has been no major advance but neither has there been a retrogression in Poland. The papers I read at Varna were almost uniformly competent, although nothing particularly exciting was being said about Polish society. Perhaps this is the fate of relatively mature and developed sociology in stagnant societies where it does not become a critique of the existing system.

In Poland one finds a phenomenon which is even more common in Yugoslavia. This is the special role of epistemology and independent Marxist theoretical sociology (and philosophy) as the conceptual framework on which the critical sociologists base themselves. I have referred to this earlier, but there is a pattern that is common to a number of countries. Critical sociology is now found openly in Yugoslavia; a more muted form was present in Czechoslovakia during the Dubček period, and among the Polish sociologists 
and philosophers before 1968. A very guarded version can be seen in Hungary, based on the work of Lukács.

Apparently after the stage of Marxist orthodoxy passes, there is the development of an almost idea-free-in effect politics-free-social science. It is essential for the social science to develop a minimal autonomy from direct political control if it is to be of any functional use to the system managers. Once there is a body of empirical work and data to refer to, a clash between the normative descriptions and the social reality of the society becomes increasingly apparent. At this stage there is a further evolution-some social scientists become experts in social policy for the policy-making bodies, advocating changes that would rationalize the system, while others become social critics.

The tools for a critical theory are found ready-made in Marxism, particularly in the young Marx. The critiques tend to be on a relatively high level of abstraction for two reasons-the original philosophical training of so many of the critics, and the simple fact that abstract criticism is far more likely to be tolerated. This is one of the reasons for the revival of the young Marx and the emphasis on the themes of alienation and freedom. A further reason, of course, is that Marx's more political writings are a critique of capitalist society and it is therefore in the Marxist philosophy and epistemology that roots are sought for a theoretical critique of the existing social order in Eastern Europe.

\section{Yugoslavia}

Polish sociology is much better known in the West than Yugoslav sociology for at least two reasons: the Poles were the first of the East Europeans to enter into a dialogue with their Western counterparts, and Polish sociology is reasonably centralized and has benefited from the relatively generous subsidies in the past for its publications and translations. The Yugoslavs, on the other hand, receive little or no central funds for academic representation and, more to the point, are so diverse that it is almost impossible to talk of a Yugoslav sociology. Rather one can discuss Yugoslav sociologists, or schools of sociology.

The development of social science and sociology in Yugoslavia is of special interest because it represents the most developed stage of the discipline in the whole area. It shows the maximum range of possibilities and the extreme limits of development possible for sociology in Eastern Europe within the existing social order. This is often recognized in private conversations by their East European colleagues, who show not a little envy of the conditions under which the Yugoslavs work. What is less often recognized is that this greater freedom from state and party interference is paid for with budgetary 
uncertainties and crises, and a general absence of the fringe benefits and "perks" available to the more domesticated academics in other countries.

The basic framework within which the development of sociology and empirical social research in Yugoslavia should be considered is that of a continual political and social experimentation through which the society has grown increasingly decentralized, and in which a multiplicity of avenues for participation within the social and political system have developed. This process has been characterized by a secularization of the political elite, with a corollary secularization of social science.

Decision-making bodies on all levels, ranging from the federal legislature through the republics and down to the commune, have long ceased to act as a sounding board for official pronouncements and rhetoric. The resulting debate is of considerable significance to the government and society. What is characteristic of the debate, given the absence of organized opposition, is the continual reference, both by the official leaders and critics, to objective or impartially presented information about matters under discussion. This information is provided largely by social science. In this way the social sciences have attained a significance and policy relevance unimaginable elsewhere. The same relationship holds for the mass organizations, the League of Communists, trade unions, socialist alliance, youth, the women's organization, and so forth-all of which either employ trained sociologists or contract studies from the existing institutes and university research teams. This is also true of the mass media. Thus, in addition to the social science journals, social researches and findings are freely used by publicists in the general press. One notes that even political and literary journals publish tables. The special role of sociology in Yugoslavia is perhaps symbolized by the presence of a major Yugoslav sociologist, Dr. Miroslav Pečujlić, ${ }^{26}$ in the presidium of the Executive Committee of the League of Communists, the highest policy-making body of the league.

The Yugoslav political decision-makers and social scientists regard their social system as a unique one with general applicability, particularly to developing societies. It is regarded not as a more liberal version of East European socialism but as an alternate model. They are thus conscious that their experiments with workers' control, communal self-government, decentralization, economic reform, and development of a multinational polity have moved them into unfamiliar waters, and they require a great deal of information about the performance of the system. Studies of workers' self-management, for example, have proliferated to such an extent that a printed bibliography of

26. Miroslav Pečujlić has primarily been involved in research on social stratification and social change. His Klase $i$ savreneno društvo [Classes and Contemporary Society] (Belgrade, 1967) is a standard textbook on the subject. In 1967 he launched a major "macro-project" to study the changes in the social structure in contemporary Yugoslavia. 
works and studies on that subject in 1968 numbered over three hundred pages! As far back as 1961 the International Social Science Journal gave as over seventy the number of institutes, research groups, university seminars, and other establishments conducting social science research. ${ }^{27}$ Until the recent pressures toward consolidation, Parkinson's Law assured that this number increased.

A special feature in the institutional development of Yugoslav society is that the discipline increasingly reflects the devolution of state and league authority from the federation to the republics. Thus, each of the six republics and two autonomous provinces has its own social science institution, which has minimal contact with the others. The better-developed centers in Belgrade, Zagreb, and Ljubljana often have better contacts with the work of their colleagues abroad than with each other, a feature encouraged by the freedom of travel and contact. Although this develops a type of provincialism, it also encourages a pluralism in the content of research conducted, and the definition of the discipline. To be sure, divergences among Yugoslav sociologists do not follow institutional lines, the major currents being present in most centers. These three currents could be very roughly defined as follows:

1. Establishment sociologists-a group conducting relatively little research into "touchy areas," primarily concerned with providing an academic version of the normative Marxist description of their society. These tend to be as often as not the retrained sociologists-that is, those who never had any sociological training. Since "science of society" has long replaced Marxism-Leninism as the compulsory subject in secondary schools and universities, there is a ready-made role for this group.

2. Empiricists-found in increasing numbers in the social science institutes and among the depoliticized younger faculty and graduate students. This is probably the largest group of sociologists and researchers. Technically well trained, they conduct a large proportion of the studies needed by the various institutions. The influence of Western sociology is greatest with this current, and they tend toward a form of pragmatism which attracts them above all to applied social science. They are a product of the growing autonomy and secularization of sociology in Yugoslavia.

3. Critical sociologists-found primarily but not exclusively in the faculties. This group is greatly influenced by Praxis, the journal of the Zagreb philosophers whose slogan, "criticism of all that exists," sets the tone for much of their work. Praxis, of course, is not only a Yugoslav publication, as a glance at its international editorial board shows. ${ }^{28}$

27. International Social Science Journal, vol. 13, no. 3 (1961); the issue is mostly devoted to the problem of Yugoslav local government. An up-to-date review of the organizational state of social research is found in the Yugoslav Research Guide.

28. The board includes Zygmunt Baumann, Norman Birnbaum, Ernst Bloch, 
Yugoslav critical sociologists find themselves in continual conflict with functionalism and empiricism, which they view as being imported wholesale to create a service-oriented social science for their own establishment. They stress themes of alienation, freedom, and conflict-conflict, in this case, within their own society: of underprivileged against privileged, workers against bureaucracy, intellectuals against technocrats and party bureaucrats, and so forth. They are Marxists, probably more explicitly and committedly than any other group, but for them Marxism is a critical social science rather than an official ideology. Younger members of this current have produced some excellent recent studies of strikes, ${ }^{29}$ student demonstrations, social stratification, sociology of culture, and political socialization. Being critics, they tend to have less access to research funds than their more conformist colleagues, a situation not unfamiliar to their Western colleagues. In their theoretical writings about Yugoslav society they stress more than any other group the uniqueness of $\mathrm{Yu}$ goslav socialism and its sharp divergence from the other East European systems. For that matter, a number of them would not apply the term "socialist" to any of those regimes.

The whole range of social science disciplines known in the West is represented in Yugoslavia. Extensive contacts with foreign scholars, universities, and research centers have existed for over a decade. Most major centers of research have been involved in at least some cross-national or joint research with colleagues from France, England, or the United States. On the other hand, there has been little contact and even less collaboration with colleagues from Eastern Europe. This is because the Yugoslavs see little benefit from such collaboration, while the East Europeans, or at least their official circles, regard the Yugoslav sociologists of whatever variety as revisionists.

The three basic groups of Yugoslav sociologists I have discussed have a great deal in common. To begin with, they have excellent access to works of Western and classical sociologists, both in the original version and in translation. ${ }^{30}$ The increasing number of competent professionally trained sociologists has done much to raise the norm of discussion in the professional journals and meetings. And last, there is a feeling of continual expansion of the range of problems and questions which can be legitimately studied.

Thomas Bottomore, Erich Fromm, Jürgen Habermas, Leszek Kolakowski, Henri Lefebvre, Georg Lukács, Serge Mallet, Herbert Marcuse, David Riesman, and Kurt H. Wolff, a mixture of philosophers and sociologists best described as Marxist humanists whose very names are anathema to the party ideologues of the USSR and Eastern Europe.

29. Two good examples are Nebojsa Popov, "Strajkovi u savremenom jugoslovenskom društvu" [Strikes in Contemporary Yugoslav Society], Sociologija, vol. 11, no. 4 (1969), and the round table "Fizionomija jednog strajka" [The Physiognomy of a Strike], Pogledi, vol. 2, no. 3 (1970).

30. The translations are far from being limited to "approved" works; one of the latest translations to appear in Belgrade is Seymour Martin Lipset, The Political Man. 
In the last few years even the most delicate questions seem accessible to social scientists. Not only do public opinion polls deal with most current social and political questions, and the findings are published, but these questions are also dealt with in the recent work of political sociologists. ${ }^{31}$ The writings of Zoran Vidaković, Stipe Suvar, Ljubomir Tadić, and Rudi Supek, ${ }^{32}$ to name only the more prominent figures, are concerned directly and critically with some of the basic problems of socialist societies, and of Yugoslav society in particular-the social role and power of the working class, the national question and the problem of inequality, social order and freedom, and the social composition and role of the political elite. All but Tadić use empirical data. However, all of them deal with central problems which are traditionally in the domain of the official ideology and the ruling party-that is, with problems on which there is a "line." In each case, they argue a divergent thesis.

Thus, in terms of both my model and the practice in the countries with highly developed sociology, there is no further stage for Yugoslav sociology to develop to. The limits which exist are those of the capacity of the individual scholar or his institutions, the perennial shortage of funds (familiar to all free academics), and the presence or absence of personal political ambition or careerism. In short, these are limits which most Western social scientists recognize as normal. In this respect, the Yugoslav situation represents a goal for the social scientists of Eastern Europe and the USSR. This is not the least reason for the continual polemics directed against the Praxis group by the Russians and others. The Yugoslavs illustrate that it is possible to develop a free social science without endangering the social system. Of course, the question is, To what extent is this a function of the kind of social system involved? The answer to that question will be found only in the further developments in Eastern Europe and the USSR.

31. Both political sociology and political science are established in Yugoslavia, the latter with three faculties. The published works, too numerous to cite, range from the parliamentary system to problems of political power. While a number of works are normative in character, Pavel Novosel of Zagreb and Milan Matić of Belgrade are empirical political scientists. An interesting work in English is Branko Horvat's $A n$ Essay on Yugoslav Society (White Plains, 1970), which, although the product of a leading political economist, is a work of political sociology. See the English edition in Sociologija (1970) for a selection of the major articles from 1959 to 1969.

32. Zoran Vidaković, Društzena moć radničke klase [Social Power of the Working Class] (Belgrade, 1970); Stipe Suvar, Presek jugoslovenskog društva [The Anatomy of Yugoslav Society] (Zagreb, 1970); Ljubomir Tadić, Poredak i sloboda [Social Order and Freedom] (Belgrade, 1967); Rudi Supek, Elite $i$ moć [Elites and Power] (Zagreb, in preparation). Supek and Tadić are members of the Praxis editorial board. Supek's book is based on a comparative study of elites, including Yugoslav political elites. Some of his theses are available in English in Working Papers of the International Study of Opinion-Makers, vols. 2 and 3 (mimeographed), Bureau of Applied Social Research, Columbia University. 